Historic, Archive Document

Do not assume content reflects current scientific knowledge, policies, or practices. 

Department of Agriculture

Forest Service

Rocky Mountain Forest and Range Experiment Station

Fort Collins,

Colorado 80526

Research Paper RM-RP-320

雨空

\section{Evaluating the Habitat Capability Model for Merriam's Turkeys}

Mark A. Rumble

Stanley H. Anderson

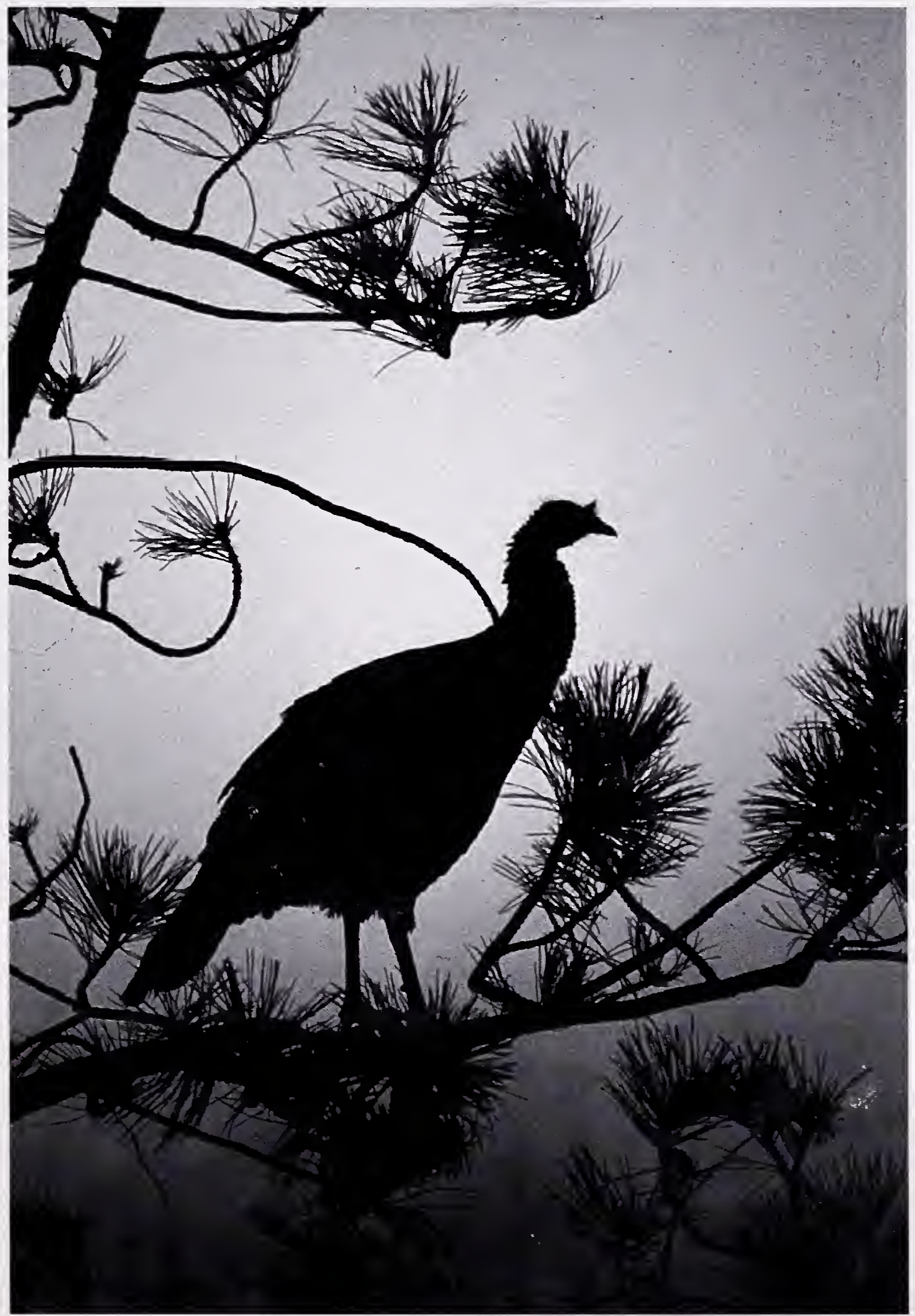


Rumble, Mark A; Anderson, Stanley H. 1995. Evaluating the Habitat Capability model for Merriam's turkeys. Res. Pap. RM-320. Fort Collins, CO: U.S. Department of Agriculture, Forest Service, Rocky Mountain Forest and Range Experiment Station. 8p.

Habitat capability (HABCAP) models for wildlife assist land managers in predicting the consequences of their management decisions. Models must be tested and refined prior to using them in management planning. We tested the predicted patterns of habitat selection of the R2 HABCAP model using observed patterns of habitats selected by radio-marked Merriam's turkeys (Meleagris gallopavo merriami) in the Black Hills, South Dakota. Coefficients for winter required substantial revision, coefficients for summer were modified to a lesser extent. Coefficients are recommended for winter, summer, and poult habitats.

Keywords: Merriam's turkeys, habitat, management, habitat models, Meleagris gallopavo merriami

Mark Rumble is a Research Wildlife Biologist with the Rocky Mountain Station in Rapid City. He has a B.S. from Washington State University, M.S. from South Dakota State University, and Ph.D. from University of Wyoming. Research interests include livestock and forest management and wildlife habitat relationships. He researched Merriam's turkey habitat relationships in the Black Hills, South Dakota for 6 years.

Stan Anderson is the Unit Leader for the Wyoming Cooperative Fish and Wildlife Research Unit in Laramie. He as a B.S. from University of Redlands and M.A. and $P h . D$. from Oregon State University. Stan has been pursuing research interests in avian and mammal habitat ecology and factors that affecting wildlife populations in relation to land management for more than 25 years. 


\title{
Evaluating the Habitat Capability Model for Merriam's Turkeys
}

\author{
Mark A. Rumble, Research Wildlife Biologist \\ Rocky Mountain Forest and Range Experiment Station ${ }^{1}$ \\ Stanley H. Anderson, Unit Leader \\ USDI National Biological Service \\ Cooperative Fish and Wildlife Research Unit ${ }^{2}$
}





\section{Contents}

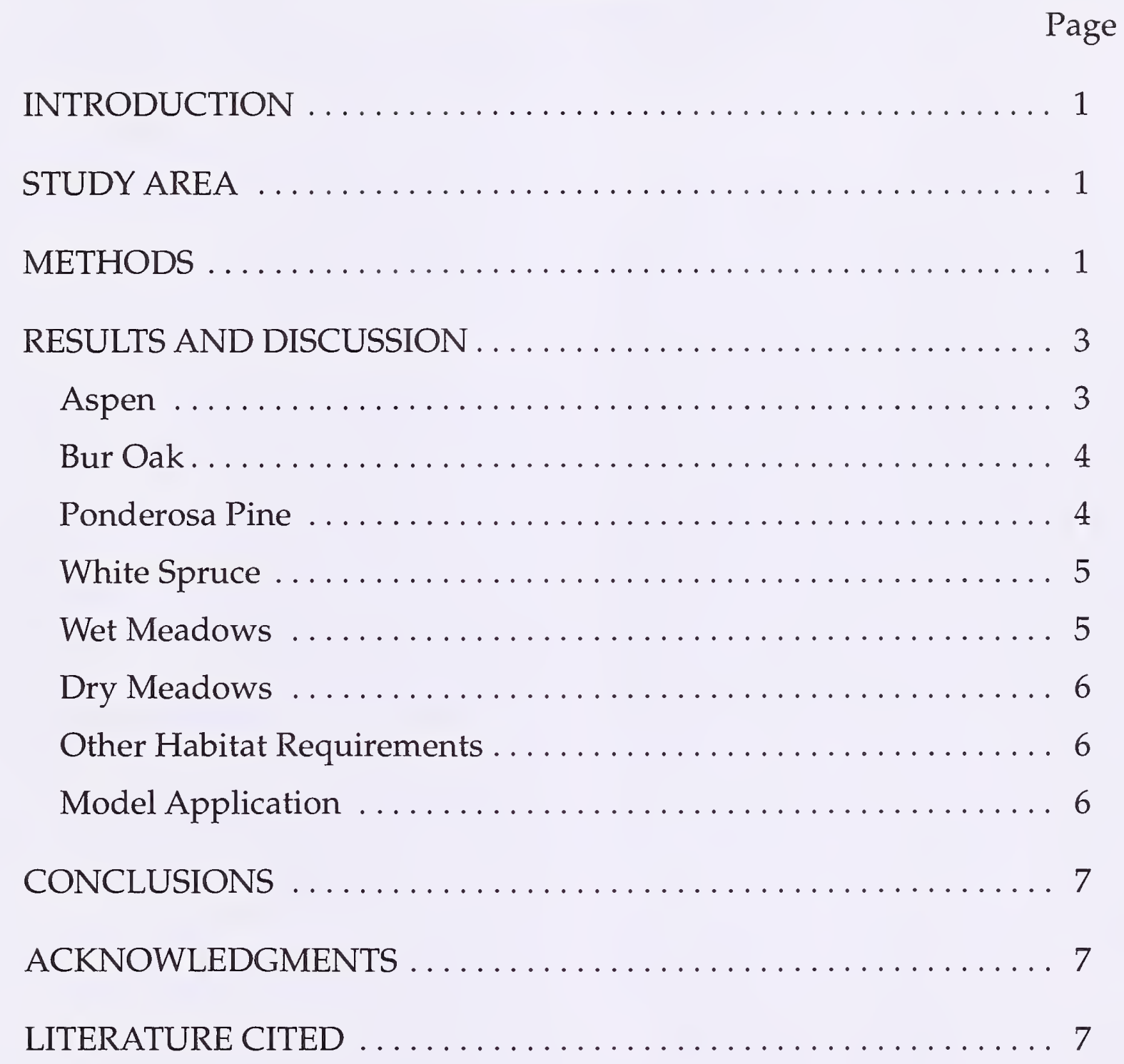





\title{
Evaluating the Habitat Capability Model for Merriam's Turkeys
}

\author{
Mark A. Rumble and Stanley H. Anderson
}

\section{INTRODUCTION}

Models of wildlife species interactions with their environments provide biologists with tools to examine quality of wildlife habitats. Wildlife habitat models also stimulate research of hypotheses regarding habitat interactions of species. Although habitat models have utility, they also have shortcomings (Van Horne 1983) that result from violations of their assumptions and their inability to simplify complex interactions between animals and their habitats.

Wildlife habitat capability (HABCAP) models used by the USDA Forest Service were first proposed by Thomas (1979) as a method for evaluating wildlife habitats in relation to timber management and succession on forested lands. Hoover and Wills (1984) proposed similar models for the Rocky Mountain Region of the Forest Service. The Black Hills National Forest uses HABCAP models to evaluate impacts of proposed management activities and monitor habitats of wildlife. Decisions affecting land management activities, which also have social and economic impacts, are made considering the predictions of HABCAP models. Therefore, these models need to be tested and improved so they accurately predict the habitat relationships of wildlife species. The objective of this study was to test the predicted habitat selection patterns based on the HABCAP model for Merriam's turkeys (Meleagris gallopavo merriami) against habitat selection patterns determined by radio telemetry.

\section{STUDY AREA}

This study was conducted in the central Black Hills, South Dakota. Vegetation is mostly forest and woodland composed of ponderosa pine (Pinus ponderosa), but includes meadows, quaking aspen (Populus tremuloides)/paper birch (Betula papyrifera), bur oak (Quercus macrocarpa), and white spruce (Picea glauca) and interspersed by meadows. Descriptions of the vegetation, climate and geology of the area are detailed in Rumble and Anderson (1993a). For general information about the Black Hills ecoregion, see Bailey (1995).

\section{METHODS}

This study was conducted from March 1986 to January 1989. We trapped Merriam's turkeys during late February to early March each year using rocket nets or drop nets over corn bait. Forty-four turkeys (36 females and 8 males) were fitted with backpack radio transmitters weighing approximately $108 \mathrm{~g}$. After a 1-week adjustment period to the transmitters (Nenno and Healy 1979), each bird was located three times each week. Locations were estimated by plotting $\geq 2$ telemetry bearings on USGS 1:24,000 contour maps in the field. The bearings were taken $<300$ $\mathrm{m}$ from the birds using a two-element hand-held antenna. Each location was assigned to a habitat unit at the time the location was made. Most habitat units varied between 4 and 32 ha in size. The boundaries of habitat units were delineated by changes in dominant vegetation type, ridges, valleys, or roads. Thus, we were able to accurately assign locations of birds to the proper habitat unit. Twenty-seven percent of all locations were direct observations of birds or from close-range $(<50 \mathrm{~m})$ telemetry.

Vegetative descriptions of habitat units were based on dominant vegetation types, diameter at breast height (DBH), and overstory cover (Buttery and Gillam 1983). These descriptions, hereafter referred to as structural stages and the acronyms used for them, occur in table 1. Our study included 513 habitat units in 13 structural stages. The HABCAP model recognizes structural stages of meadows, wet and dry. We considered subirrigated meadows dominated by Kentucky bluegrass (Poa pratensis) and smooth brome (Bromus inermis) as wet meadows. Dry meadows were comprised of species typical of mixed-grass steppe (Hamm 1973, Bennett 1984).

HABCAP models coefficients between 0 and 1.0 represent the relative ability of a structural stage to 
Table 1.-Vegetation type structural stage, DBH, overstory cover, and HABCAP model acronyms for structural stage evaluated for Merriam's turkeys in the Black Hills, South Dakota.

\begin{tabular}{|c|c|c|c|c|}
\hline Vegetation type & Structural stage & $\mathrm{DBH}(\mathrm{cm})$ & Overstory cover $(\%)$ & Acronym \\
\hline \multirow[t]{5}{*}{ Ponderosa Pine } & Grass/forb & NA & 0 & $\mathrm{Pl}$ \\
\hline & Seedling/shrub & $<2.5$ & 0 & P2 \\
\hline & Sapling/pole & $2.5-25.0$ & $0-40$ & P3A \\
\hline & & & $41-70$ & P3B \\
\hline & & & $>71$ & P3C \\
\hline \multirow[t]{3}{*}{ Ponderosa Pine } & Mature & $>25.0$ & $0-40$ & P4A \\
\hline & & & $41-70$ & P4B \\
\hline & & & $>71$ & P4C \\
\hline \multirow[t]{4}{*}{ Aspen } & Seedling/shrub & $<2.5$ & 0 & A2 \\
\hline & Sapling/pole & $2.5-25.0$ & $0-40$ & A3A \\
\hline & & & $41-70$ & A3B \\
\hline & & & $>70$ & $\mathrm{~A} 3 \mathrm{C}$ \\
\hline \multirow[t]{3}{*}{ Bur Oak } & Grass/forb & NA & 0 & 01 \\
\hline & Seedling/shrub & $<2.5$ & 0 & $\mathrm{O} 2$ \\
\hline & Sapling/pole-Mature & $>2.5$ & $0-100$ & OAK \\
\hline White Spruce & Sapling/pole-Mature & $>2.5$ & $0-100$ & SPR \\
\hline Kentucky Bluegrass Meadow & NA & 0 & WM & \\
\hline Upland Meadow & & NA & 0 & DM \\
\hline
\end{tabular}

' Kentucky bluegrass meadows are considered wet meadows and upland meadows are considered dry meadows.

support Merriam's turkeys. The model included coefficients for feeding and cover with separate coefficients for summer and winter. We could not accurately determine the behavior of birds at each location so we combined the coefficients for feeding and cover for analyses. Habitat selection of energy maximizers (Schoener 1971) is determined by the search for food; and this pattern is applicable to Merriam's turkeys. Therefore, combined HABCAP coefficients were weighted 3:1 in favor of the feeding coefficient. We used locations of turkeys between November and March to evaluate winter HABCAP model coefficients and June to September to evaluate the summer HABCAP model coefficients. The HABCAP model did not include coefficients for poult habitats. Habitat selection and protein requirements change for poults $>8$ weeks old (National Research Council 1977, Robbins 1983, Rumble and Anderson 1993b). We used locations of poults $<8$ weeks old and summer coefficients to evaluate the HABCAP model for poult habitats. We also present HABCAP coefficients for roosting based on qualitative assessments of previous analyses of Merriam's turkeys roost habitats (Rumble 1992).
We tested the hypothesis that predicted selection of structural stages by the HABCAP model was similar to observed selection by turkeys using chi-square goodness-of-fit tests (Freese 1960). To increase independence among observations, locations of individual birds were $>1$ day apart and simultaneous locations of $>1$ radio-marked bird were tallied as a single observation (Alldredge and Ratti 1986, Jelinski 1991). Predicted selection of structural stages was determined by calculating a relative coefficient, weighted by proportional area for each structural stage and multiplying it times the number of observations $(\mathrm{N})$. The formula used was

$$
\text { Predicted use }=\frac{C_{i}}{\sum C_{i} P_{i}} N
$$

where $C_{i}$ represents the weighted coefficient for structural stage $i, P_{i}$ represents the proportional area of structural stage $i$, and $N$ represent the total number of radio locations.

Structural stages with model coefficients of 0 were not included in chi-square tests. Confidence intervals around the proportion of observations occurring in 
each structural stage (Fleiss 1981) were made using a Bonferroni correction to $\alpha$ (Neu et al. 1974). Revised HABCAP coefficients were developed through an iterative process of revising coefficients that fell outside the confidence intervals, chi-square goodnessof-fit tests, and evaluation predicted use of structural stages versus Bonferroni confidence intervals. This process was continued until we obtained a nonsignificant chi-square test. Coefficients $<0.10$ were truncated to 0 for structural stages that were rarely selected by turkeys. Statistical significance was determined at $\alpha \leq 0.05$.

\section{RESULTS AND DISCUSSION}

Merriam's turkeys in the Black Hills selected structural stages different $\left(X^{2} \geq 254,9 d f, P<0.01\right)$ from patterns predicted by the HABCAP model (table 2). Revised HABCAP coefficients resulted in good fit between predicted and observed selection of structural stages during winter $(P=0.20)$, summer $(P=0.15)$ and poults $(P=0.40)$. Predicted use by turkeys in some structural stages did not fall within the confidence intervals around observed use after a nonsignificant chi-square was achieved. We modified these coefficients to the extent we felt they were biologically meaningful, but predicted use for some structural stages remained outside the confidence interval in the final model.

\section{Aspen}

Sapling-pole aspen/birch 0-40 percent and 41-70 percent overstory cover (A3A and A3B) structural stages are patchy, with small openings with grasses, forbs and shrubs. Most (71 percent) turkeys using aspen/birch during winter occurred in A3B. Turkeys selected aspen/birch structural stages during late winter-spring when diets of turkeys included more green vegetation. We propose winter coefficients for of 0.3 for A3A and 0.4 for A3B. Predicted use of A3B was less than indicated by the confidence intervals in the final model. Winter foods of turkeys in the Black Hills are mostly ponderosa pine seeds and kinnikinnick (Arctostaphylos uva-ursi) fruits. Both of these foods are scarce in aspen/birch, and we do not believe a larger coefficient was warranted for A3B. Sapling-pole aspen/birch $>71$ percent overstory cover (A3C) structural stages in drainages usually have a dense shrub layer $<1.5 \mathrm{~m}$ tall comprised of beaked hazelnut (Corylus cornuta). Turkeys prefer habitats with open understory (Bailey and Rinell 1967) probably because tall shrubs inhibited the bird's field of vision. A3C structural stages had coefficients of 0 , and thus even one observation was outside the confidence interval in the initial model, but the coefficient in the revised model remained at 0 . Habitat characteristics selected by turkeys in aspen are probably similar among size classes of trees and we recommend similar HABCAP coefficients for DBH Table 2.-Old HABCAP model coefficients, $95 \%$ Bonferroni confidence intervals $(\mathrm{Cl})$ on percent observed $\left(\mathrm{P}_{\text {obs }}\right)$, proposed
new HABCAP model coefficients, and percent of observations predicted $\left(\mathrm{P}_{\text {pred }}\right)$ from proposed model coefficients in
vegetative structural stages for Merriam's turkeys in the Black Hills, South Dakota.

\begin{tabular}{|c|c|c|c|c|c|c|c|c|c|c|c|c|c|c|}
\hline \multirow[b]{2}{*}{$\begin{array}{l}\text { Structural } \\
\text { stage }\end{array}$} & \multicolumn{5}{|c|}{ Winter $N=449$} & \multicolumn{5}{|c|}{ Summer $N=174$} & \multicolumn{4}{|c|}{ Poults $N=171^{1}$} \\
\hline & $\begin{array}{l}\text { Old } \\
\text { coef }\end{array}$ & $\ldots$ & bs & $\begin{array}{l}\text { New } \\
\text { coef }\end{array}$ & $P_{\text {pred }}$ & $\begin{array}{l}\text { Old } \\
\text { coef }\end{array}$ & $\cdots$ & obs $=--$ & $\begin{array}{l}\text { New } \\
\text { coef }\end{array}$ & $P_{\text {pred }}$ & $\cdots C l$ & $P_{\text {obs }}=-\cdot$ & $\begin{array}{l}\text { New } \\
\text { coef }\end{array}$ & $P_{\text {pred }}$ \\
\hline $\mathrm{A} 3 \mathrm{~A}$ & 0 & 0.4 & 3.8 & 0.3 & 0.7 & 1.0 & 0.5 & 7.9 & 0.5 & 1.7 & $<.1$ & 5.4 & 0.3 & 1.5 \\
\hline $\mathrm{A} 3 \mathrm{~B}$ & 0 & 1.9 & 7.1 & 0.4 & 1.2 & 0.6 & 4.3 & 16.2 & 1.0 & 4.3 & 0.3 & 7.2 & 0.5 & 3.3 \\
\hline$A 3 C$ & 0 & $<.1$ & 2.1 & 0 & 0 & 0.6 & 0.1 & 6.2 & 0.2 & 0.9 & 0.6 & 8.1 & 0.2 & 1.3 \\
\hline P3A & 0.9 & 0.5 & 4.1 & 0.2 & 2.3 & 1.0 & 10.4 & 25.6 & 1.0 & 15.9 & 3.2 & 14.3 & 0.4 & 9.6 \\
\hline P3B & 0.5 & 13.1 & 22.6 & 0.6 & 16.2 & 0.5 & 12.7 & 28.8 & 0.4 & 15.2 & 11.9 & 28.0 & 0.3 & 17.3 \\
\hline P3C & 0.3 & 24.0 & 35.4 & 0.8 & 28.0 & 0.5 & 8.5 & 23.0 & 0.3 & 14.8 & 4.4 & 16.5 & 0.1 & 7.5 \\
\hline P4A & 1.0 & 2.9 & 8.7 & 0.5 & 3.8 & 1.0 & 2.8 & 13.3 & 1.0 & 10.7 & 2.8 & 13.6 & 0.4 & 6.5 \\
\hline$P 4 B$ & 0.6 & 19.3 & 30.0 & 0.8 & 26.8 & 0.6 & 9.0 & 23.6 & 0.4 & 18.9 & 11.5 & 27.3 & 0.3 & 21.5 \\
\hline P4C & 0.4 & 9.8 & 18.5 & 0.9 & 17.9 & 0.4 & 4.7 & 16.9 & 0.3 & 8.4 & 0.8 & 8.9 & 0.1 & 4.3 \\
\hline WM & 0 & 0.5 & 4.1 & 0.2 & 1.2 & 0.9 & 1.4 & 10.3 & 0.3 & 2.6 & 16.8 & 34.3 & 1.0 & 13.1 \\
\hline DM & 0.4 & 0.3 & 3.5 & 0.2 & 2.1 & 1.0 & $<.1$ & 4.3 & 0.3 & 4.5 & 2.8 & 13.6 & 0.5 & 11.3 \\
\hline OAK & 0.9 & $<.1$ & 2.7 & 0.5 & 0.4 & 0.4 & 0.1 & 6.2 & 0.8 & 0.8 & 0.3 & 7.2 & 0.8 & 1.2 \\
\hline SPR & 0 & NA & & 0 & 0 & 0.5 & 0.3 & 7.1 & 0.6 & 0.3 & $<.1$ & 5.4 & 0.2 & 0.2 \\
\hline
\end{tabular}

'The HABCAP model did not include coefficients for poults, so we use summer coefficients in this test. 
structural stage 4 of aspen as for structural stage 3 . We believe it is unlikely that Merriam's turkey populations could be sustained in the Black Hills throughout the winter in aspen/birch.

Dense shrub conditions in $\mathrm{A} 3 \mathrm{C}$ also detracted from use during summer by turkeys. Otherwise, only slight modifications to summer HABCAP model coefficients in aspen were made. The coefficients we propose for poults in aspen/birch are lower than summer coefficients in the old model and were in close agreement with observed selection of aspen by brood hens. Grasshoppers (Orthoptera), the preferred food of poults, were uncommon in aspen.

Coefficients for aspen/birch structural stages for which we do not have data to test are in table 3 . We based our revision of these coefficients on habitat conditions and habitat requirements of Merriam's turkeys. Aspen rapidly sprouts following logging or other disturbance; the grass / forb structural stage of aspen (A1) is very short in duration (Schier et al. 1985). Thus, the A1 structural stage would be unimportant as Merriam's turkey habitat; and we recommend no coefficient be assigned to it. The shrub-seedling structural stage of aspen/birch (A2) is probably too dense and would likely be avoided by adult turkeys (Holbrook and Lewis 1967). A winter coefficient of 0 for the A2 structural stage should continue to be used. Merriam's turkeys could use the A2 during summer and as poult habitat, but the value of this would not be greater than other aspen/birch habitats. In Utah, Merriam's turkeys selected openings in aspen habitats during summer (Bryant and Nish 1975). We propose coefficients of 0.3 for summer and poults for the A2 structural stage.

\section{Bur Oak}

Bur oak comprised only 0.4 percent of the study area, most of which occurred in association with Kentucky bluegrass or western snowberry (Symphoricarpos occidentalis) in narrow ( $<50 \mathrm{~m}$ across) subirrigated meadows. We combined all structural stages of bur oak in our analyses, but there were too few observations of turkeys in oak habitats to make strong statements about the values of these structural stages to Merriam's turkeys in the Black Hills. Bur oak and Gambel's oak (Q.gambellii)/ponderosa pine habitats are common in Merriam's turkey range. Most western oaks are infrequent producers of mast, with crops occurring at 2-7 year intervals (Olson 1974). In the Black Hills, mast crops of bur oak are unpredictable and acorns are frequently parasitized
Table 3.-Old and proposed new HABCAP model coefficients for Merriam's furkeys, not tested in the Black Hills, South Dakota.

\begin{tabular}{lcccccc}
\hline \multirow{2}{*}{$\begin{array}{l}\text { Structural } \\
\text { stage } \\
\text { acronym }\end{array}$} & \multicolumn{2}{c}{ Old coefficients } & & \multicolumn{3}{c}{ Revised coefficients } \\
\cline { 2 - 3 } \cline { 5 - 7 } & Winter & Summer & & Winter & Summer & Poults \\
\hline A2 & 0.0 & 1.0 & & 0.0 & 0.3 & 0.3 \\
O1 & 0.3 & 1.0 & & 0.1 & 0.3 & 0.5 \\
O2 & 0.5 & 1.0 & & 0.1 & 0.5 & 0.3 \\
P1 & 0.3 & 1.0 & & 0.1 & 0.3 & 0.5 \\
P2 & 0.8 & 1.0 & & 0.1 & 0.3 & 0.3 \\
\hline
\end{tabular}

by Curculio spp. It is unlikely that structural stages of bur oak in the Black Hills could support a large turkey population. When mast crops in oak occurred, turkeys used these habitats for 2-4 weeks, but use may also have been limited by the distribution and abundance of these habitats. Merriam's turkeys in Arizona actively selected for acorns as a winter food (Wakeling and Rogers, in press). We recommend revising the HABCAP coefficients for Merriam's turkeys in the tree structural stages of bur oak to 0.5 during winter. The coefficients for structural stages of oak should increase with greater overstory cover, but data are lacking. We recommend a summer coefficient of 0.8 for bur oak in the Black Hills. Because herbaceous biomass and invertebrate abundance decline with increased overstory cover, coefficients for summer and poults should decline with greater overstory cover. Research is needed to validate coefficients in bur oak habitats. If oak occurs on slopes, its value to poults would be reduced because herbaceous biomass would be lower than occurred in the drainages in our study. The proposed coefficients for bur oak grass-forb (O1) and shrub-seedling (O2) structural stages reflect upland bur oak sites. These structural stages result from clearcut harvesting or fire, which are unlikely disturbances to bur oak in meadows or drainages.

\section{Ponderosa Pine}

Ponderosa pine is the dominant vegetation type in the Black Hills and turkeys selected ponderosa pine structural stages year-round. Substantial revisions were necessary to winter coefficients in the HABCAP model to make predicted selection compliant with observed selection of ponderosa pine structural stages. Old model coefficients indicated that habitat capability in ponderosa pine decreased as overstory cover increased and probably resulted from literature suggesting that winter turkey diets 
in the southwest were mostly seeds and leaves of grasses and forbs (Scott and Boeker 1975). Coefficients in the old model for sapling-pole and mature ponderosa pine $>71$ percent overstory cover ( $\mathrm{P} 3 \mathrm{C}$ and P4C) structural stages emphasized cover. Ponderosa pine seed is the preferred winter food of Merriam's turkeys in the Black Hills, and birds selected habitats where pine seed abundance was $4 \times$ greater than average (Rumble and Anderson, in press a). Pine seed abundance increases with overstory cover. When pine seeds are not available, turkeys select ponderosa pine habitats with less canopy closure and diets include kinnikinnick fruits, grass seeds, and grass leaves. Merriam's turkeys in the Black Hills appeared to be in lower physiological condition during winter when these latter food items dominated in their diets. We recommend winter coefficients increase with overstory in ponderosa pine. Also, mature pine trees structural stages (DBH category 4) provide better winter habitat for Merriam's turkeys than smaller trees with comparable overstory cover. These are reflected in the coefficients.

The highest winter coefficient in our evaluation of the HABCAP model was 0.9 in P4C. Ponderosa pine seed production in the Black Hills is more consistent than elsewhere in the west (Oliver and Ryker 1980), but mixed ponderosa pine and oak stands with high overstory cover should have higher winter coefficients than pure stands of either. Mast crops are more likely to develop with greater diversity of mastproducing species (Schroeder 1985).

Old summer HABCAP coefficients for turkeys in ponderosa pine required less revisions. Turkey diets during summer are mostly seeds and leaves of herbaceous vegetation. The inverse relationship between overstory cover and abundance of vegetation (Uresk and Severson 1989) was reflected in higher coefficients in sapling-pole and mature ponderosa pine 040 percent overstory cover ( $\mathrm{P} 3 \mathrm{~A}$ and $\mathrm{P} 4 \mathrm{~A}$ ) structural stages. Only slight decreases in the summer HABCAP coefficients were necessary for saplingpole ponderosa pine 41-70 percent overstory cover (P3B), mature ponderosa pine 41-70 percent overstory cover (P4B), P3C, and P4C structural stages.

The grass-forb structural stages of ponderosa pine (P1) follow clearcuts or stand-replacing fires. We expect herbaceous productivity and habitat conditions in this structural stage are similar to the dry meadow (DM) structural stage. The coefficients we recommend for P1 structural stage, therefore, are the same as those developed for DM. The shrub-seedling struc- tural stage of ponderosa pine (P2) follows $\mathrm{P} 1$ but also occurs after the overstory removal of seed-tree harvest prescription. This structural stage is typically a patchy dense stand of small ponderosa pine with a herbaceous understory. The P2 structural stage is poor winter habitat for Merriam's turkeys but provides habitat during summer. Occasionally, we observed turkeys loafing in these dense stands of small pine trees during spring and summer. Reduced herbaceous biomass in the P2 structural stage versus P1, would lower habitat capability for poults.

\section{White Spruce}

Most observations of Merriam's turkeys in white spruce were incidental. Turkeys were observed in white spruce occurring in some canyons and near streams on several occasions. Coefficients in the old HABCAP model showed white spruce as unsuitable for turkeys during winter. We also recommend a coefficient of 0 during winter. Most white spruce in the Black Hills occurs at elevations where snow accumulations prohibit selection by turkeys during winter. Turkeys have been observed in mixed spruce/ pine during winter, but research is needed to determine these habitat relationships. Spruce and mixed spruce/ pine were used by some radio-marked birds during summer, but outside our study area. Considering the summer diets of turkeys, we have no reason to believe that summer HABCAP coefficients in white spruce structural stages would deviate from those in ponderosa pine. Similarly, HABCAP coefficients for poults in white spruce should be the same as in ponderosa pine.

\section{Wet Meadows}

The HABCAP coefficient for the wet meadow (WM) structural stage during winter was 0; we recommend a coefficient of 0.2 during winter. Most observations of turkeys in meadows during winter were birds crossing to other habitats. In the Black Hills, turkeys can find similar foods to those occurring in meadows in structural stages of ponderosa pine and aspen/birch with $<70$ percent overstory cover. These structural stages also provide overhead cover. Our observations indicate turkeys were hesitant to cross openings and were extremely alert to potential overhead predators when in openings. Nevertheless, herbaceous vegetation is abundant in the WM structural stage and birds could feed there during winter. Similarly, despite abundant herbaceous production, adult birds rarely selected the WM structural stage during 
summer. We recommend a coefficient of 0.2 for winter and 0.3 for summer for WM.

Habitat for poults is a key component of turkey habitat management (Hoffman et al. 1993), and we propose separate coefficients for poults in the revised HABCAP model. Poults require abundant invertebrate protein for muscle and feather development (National Research Council 1977, Hurst and Poe 1985). Invertebrate abundance increases with herbaceous biomass (Healy 1985, Rumble and Anderson, submitted). Kentucky bluegrass meadows (WM) are the most important habitat for poults in the Black Hills. Brood hens took poults up to $5.6 \mathrm{~km}$ to areas of WM (Rumble and Anderson 1993b). Despite assigning this structural stage a coefficient of 1.0, predicted use by turkeys was still less than observed use. Substantial reductions to coefficients for other structural stages would have been necessary if the confidence interval around observed use in WM's included the predicted use. Habitat quality for poults was high on our area (Rumble and Anderson, in press b), and brood hens could be selective of the better habitats.

\section{Dry Meadows}

Similar to the WM structural stage, turkeys were reluctant to enter open areas and selected forested habitats with herbaceous understory during summer (Rumble and Anderson 1993a). Despite no observations of adult turkeys in upland dry meadows (DM) during summer, these habitats provide some habitat for turkeys along the forest/meadow edge. We recommend a coefficient of 0.3 for adult turkeys during summer, similar to wet meadows. However, herbaceous vegetation in DM is approximately half that in WM (Hamm 1973); and thus, they provide fewer invertebrates for poults to feed on (Healy 1985). Therefore, we propose a coefficient of 0.5 for DM's, reflective of the relative herbaceous productivity in this structural stage.

\section{Other Habitat Requirements}

Roost habitats of Merriam's turkeys in the Black Hills are described in Rumble (1992). Roost sites of Merriam's turkeys averaged $23 \mathrm{~m}^{2} /$ ha basal area with trees $>25 \mathrm{~cm} \mathrm{DBH}$ (P4B and P4C structural stages) in the Black Hills. Roosts typically occur on upper portions of slopes with easterly aspects. Birds roosting in $\mathrm{P} 3 \mathrm{~B}$ and $\mathrm{P} 3 \mathrm{C}$ structural stages did so in larger trees and no roost trees were $<23 \mathrm{~cm}$ DBH. In managed stands of ponderosa pine, structural stages $<25 \mathrm{~cm}$ DBH (P3A, P3B, P3C) provide little suitable roosting habitat for turkeys. Mixed ponderosa pine/ white spruce structural stages $>25 \mathrm{~cm} \mathrm{DBH}$ and $>40$ percent overstory cover also provide suitable roosting habitat. Merriam's turkeys roost in other conifer species (Hoffman 1968, Mackey 1984, Lutz and Crawford 1987), but we only found birds roosting in ponderosa pine. We recommend coefficients for Merriam's turkey roosts of 1.0 in pine and mixed conifer DBH category 4. Roost habitats of Merriam's turkeys can be included in structural stages managed for winter habitats if they are dispersed throughout the forests. Roost coefficients for smaller DBH structural stages of conifers should be 0 , or nearly so. Deciduous vegetation types in conifer forests have little potential as roost habitat for Merriam's turkey (Shaw and Mollohan 1992) and should have roost coefficients of 0 . Merriam's turkeys will roost in marginal habitats if other components of their habitat are sufficiently high, but quality roosting habitat cannot replace poor habitats for other aspects of Merriam's turkey ecology. If coefficients for roosting are entered into the model as cover coefficients, they should not be combined with feeding coefficients. Results for feeding and (roosting) should remain separated.

Descriptions of Merriam's turkey nest sites are provided by Rumble and Hodorff (1993). Turkey nest sites are small areas $<5 \mathrm{~m}$ across where vegetation or topography obscure the view of the nest to a height of approximately $2.5 \mathrm{dm}$. Nest site selection by turkeys occurs at a finer scale of resolution than HABCAP models are applied. In most areas, availability of nest sites probably does not limit Merriam's turkey populations.

\section{Model Application}

Application of HABCAP models assumes that increasing the area of structural stages with high coefficients increases the quality of habitat. Merriam's turkeys have seasonally different habitat requirements (Rumble and Anderson 1993a,b). Thus, turkey populations will be limited by habitat quality during the season where habitat quantity and quality are lowest. The HABCAP model does not include provisions for factors limiting populations other than coefficients for structural stages. Output from the HABCAP model should be evaluated and displayed separately for categories of summer, winter, and poults.

Selection of meadows by brood hens is determined by the protein requirements of poults (Healy 1985, Hurst and Poe 1985). The HABCAP coefficients we recommend assume that management or natural fac- 
tors have not altered habitat conditions, particularly herbaceous biomass, below that which occurred during our study. Excessive grazing by domestic livestock and wild ungulates can reduce herbaceous vegetation necessary for poults. Habitat capability for poults is better estimated directly from herbaceous vegetation as represented in the Habitat Suitability Model for Merriam's turkeys (Rumble and Anderson in press b).

\section{CONCLUSIONS}

Models of wildlife habitat relationships are important tools for natural resource managers. However, habitat models should be tested and refined. The HABCAP model for Merriam's turkeys in the Black Hills required considerable refinement to coefficients before the predicted selection of habitats by turkeys corresponded to observed selection of habitats. The greatest changes were made to the winter coefficients in the model. Since habitat requirements for poults differ greatly from adults, we recommend separate model coefficients to represent capability of habitats for poults. Other special habitat needs of Merriam's turkeys, such as roosting and nesting, can probably be met by balancing the distribution of other habitat structural stages across the landscape.

\section{ACKNOWLEDGMENTS}

The USDA Forest Service, Rocky Mountain Forest and Range Experiment Station and Black Hills National Forest, National Wild Turkey Federation, and South Dakota Game, Fish and Parks provided financial support for this research. Dr. A. J. Bjugstad (deceased) provided initial advice and encouragement. K. L. Jacobson, L. J. Harris, R. A. Hodorff, T. R. Mills, C. D. Oswald, and K. J. Thorstenson provided technical assistance. M. P. Green was a volunteer throughout this study, and R. L. Taylor allowed access to his property. J. R. Squires, B. D. Wakeling, and W. C. Aney reviewed earlier drafts of this manuscript. M. J. Tarby provided the cover photo.

\section{LITERATURE CITED}

Alldredge, J. Richard, and John T. Ratti. 1986. Comparison of some statistical techniques for analysis of resource selection. Journal of Wildlife Management 50:157-165.

Bailey, R. Wayne, and Kermit T. Rinell. 1967. Management of the eastern turkey in the northern hard- woods. Pages 261-302. In: O.H. Hewitt, ed. The Wild turkey and its management. The Wildlife Society, Washington, D.C. 589p.

Bailey, Robert G. 1995. Description of the ecoregions of the United States. 2nd edition, revised and expanded. USDA Forest Service, Miscellaneous Publication 1391. Washington, DC. 108pp with separate maps.

Bennett, Daryle L. 1984. Grazing potential of major soils within the Black Hills of South Dakota. M.S. thesis. South Dakota State University. Brookings. 199p. Bryant, Fred C., and Darrell Nish. 1975. Habitat use by Merriam's turkey in southwestern Utah. Proceedings of the National Wild Turkey Symposium. 3:6-13.

Buttery, Robert F., and Bertha C. Gillam. 1983. Forest ecosystems. Pages 43-71. In: R.L. Hoover and D.L. Wills, eds. Managing forested lands for wildlife. Colorado Division of Wildlife in cooperation with USDA, Forest Service, Rocky Mountain Region. Denver, CO. 459p.

Fleiss, Joseph L. 1981. Statistical methods for rates and proportions. John Wiley and Sons, New York, N.Y. 223p.

Freese, Frank. 1960. Testing Accuracy. Forest Science 6:139-145.

Hamm, David C. 1973. Evaluation of cattle use of a deer winter range in the Black Hills. M.S. thesis. South Dakota State University. Brookings. 69p.

Healy, William M. 1985. Turkey poult feeding activity, invertebrate abundance, and vegetation structure. Journal of Wildlife Management 49:466-472.

Hoffman, Donald M. 1968. Roost sites and habits of Merriam's turkeys in Colorado. Journal of Wildlife Management 32:859-866.

Holbrook, H. L., and J. Lewis. 1967. Management of the eastern turkey in the southern Appalachian and Cumberland Plateau region. Pages 343-370. In: O.H. Hewitt, ed. The Wild turkey and its management. The Wildlife Society, Washington, D.C. 589p.

Hoover, Robert L., and Dale L. Wills, eds. 1984. Managing Forest Lands for Wildlife. Colorado Division of Wildlife in cooperation with USDA, Forest Service, Rocky Mountain Region. Denver, CO 459p.

Hurst, George, A., and William E. Poe. 1985. Amino acid levels and patterns in wild turkey poults and their food items in Mississippi. Proceedings of the National Wild Turkey Symposium. 5:133-143.

Jelinski, Dennis E. 1991. On the use of chi-square analyses in studies of resource utilization. Canadian Journal of Forest Research 21:58-65. 
Lutz, R. Scott, and John A. Crawford. 1987. Seasonal use of roost sites by Merriam's wild turkey hens and hen-poult flocks in Oregon. Northwest Science 61:174-178.

Mackey, Dennis L. 1984. Roosting habitat of Merriam's turkeys in south-central Washington. Journal of Wildlife Management 48:1377-1382.

National Research Council. 1977. Nutrient requirements of domestic animals: nutrient requirements of poultry. National Academy of Sciences. Washington, D.C. 62p.

Nenno, Edward S., and William M. Healy. 1979. Effects of radio packages on behavior of wild turkey hens. Journal of Wildlife Management 43:460-465.

Neu, Clyde W., C. Randall Byers, and James M. Peek. 1974. A technique for analysis of utilizationavailability data. Journal Wildlife Management 38:541-545.

Olson, David F. 1974. Quercus L. Oak. Pages 692703 In: C.S. Schopmeyer, tech. coord. Seeds of woody plants in the United States. USDA Forest Service, Agriculture Handbook No. 450. Washington, D.C. 883p.

Oliver, William. W., and Russell. A. Ryker. 1990. Pinus ponderosa. Pages 413-424 In: Russell. M. Burns and Barbara. H. Honkala, tech. coords. Silvics of North America: Volume 1, Conifers. USDA Forest Service, Agriculture Handbook 654. Washington, D.C. 675p.

Robbins, Charles T. 1983. Wildlife feeding and nutrition. Academic Press, Inc., New York. 343p.

Rumble, Mark A. 1992. Roosting habitat of Merriam's turkeys in the Black Hills, South Dakota. Journal of Wildlife Management 56:750-759.

Rumble, Mark A., and Stanley H. Anderson. 1993a. Macrohabitat associations of Merriam's turkeys in the Black Hills, South Dakota. Northwest Science 67:238-245.

Rumble, Mark A., and Stanley H. Anderson. 1993b. Habitat selection of Merriam's turkey hens with poults in the Black Hills, South Dakota. Great Basin Naturalist 53:131-136.

Rumble, Mark A., and Robert A. Hodorff. 1993. Nesting ecology of Merriam's wild turkeys in the Black Hills, South Dakota. Journal of Wildlife Management. 57:789-801.
Rumble, Mark A., and Stanley H. Anderson. In Press a. Microhabitats of Merriam's wild turkeys in the Black Hills, South Dakota. Ecological Applications. Rumble, Mark A., and Stanley H. Anderson. In Press b. A habitat suitability index model for Merriam's wild turkeys. Proceedings of the National Wild Turkey Symposium.

Schier, George A., John R. Jones, and Robert P. Winokur. 1985. Vegetative regeneration. Pages 2933 In: Norbet V. Debyle and Robert P. Winokur, eds. Aspen: Ecology and Management in the western United States. USDA Forest Service, Rocky Mountain Forest and Range Experiment Station General Technical Report RM-119. Fort Collins, CO. 283p. Schoener, T. W. 1971. Theory of feeding strategies. Annual Review of Biology and Systematics 11: 369-404.

Schroeder, Richard. L. 1985. Habitat suitability index models: Eastern wild turkey. USDI Fish Wildlife Service Biological Report 82(10.106). Washington, D.C. 33p.

Scott, Virgil E., and Erwin L. Boeker. 1975. Ecology of Merriam's wild turkey on the Fort Apache Indian Reservation. Proceedings of the National Wild Turkey Symposium. 3:141-158.

Shaw, Harley G., and Cheryl Mollohan. 1992. Merriam's turkey. Pages 331-349 In: J. G. Dickson, ed. The wild turkey, biology and management. Stackpole Books. Harrisburg, PA. 463p.

Thomas, Jack Ward. 1979. Wildlife habitats in managed forests: the Blue Mountains of Oregon and Washington. USDA, Forest Service. Handbook No. 553. U.S. Government Printing Office, Washington, D.C. $512 \mathrm{p}$.

Uresk, Daniel W., and Kieth E. Severson. 1989. Understory-overstory relationships in ponderosa pine forests, Black Hills, South Dakota. Journal of Range Management 42:203-208.

Van Horne, B. 1983. Density as a misleading factor of habitat quality. Journal of Wildlife Management 47:893-901.

Wakeling, Brian F., and Timothy D. Rogers. In press. Winter diet and habitat selection by Merriam's turkeys in northcentral Arizona. Proceedings of National Wild Turkey Symposium. 
The United States Department of Agriculture (USDA) prohibits discrimination in its programs on the basis of race, color, national origin, sex, religion, age, disability, political beliefs and marital or familial status. (Not all prohibited bases apply to all programs.) Persons with disabilities who require alternative means for communication of program information (braille, large print, audiotape, etc.) should contact the USDA Office of Communications at (202) 720-2791.

To file a complaint, write the Secretary of Agriculture, U.S. Department of Agriculture, Washington, DC 20250, or call (202) 720-7327 (voice) or (202) 720-1127 (TDD). USDA is an equal employment opportunity employer. 


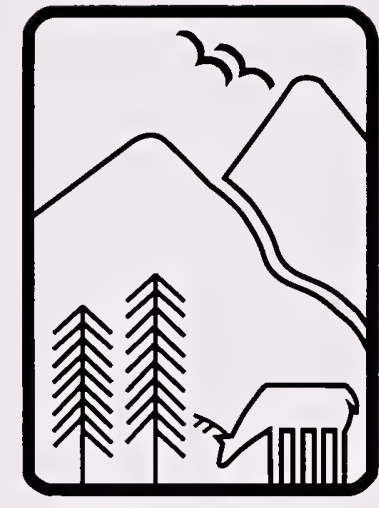

Rocky
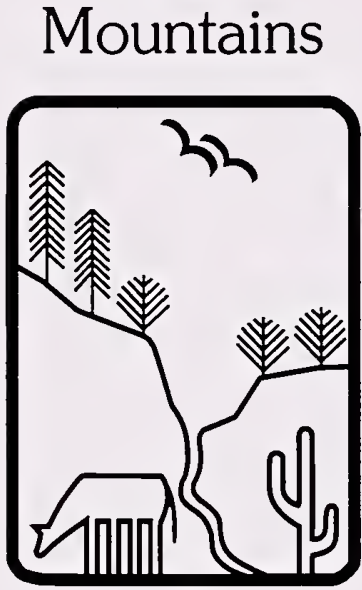

Southwest

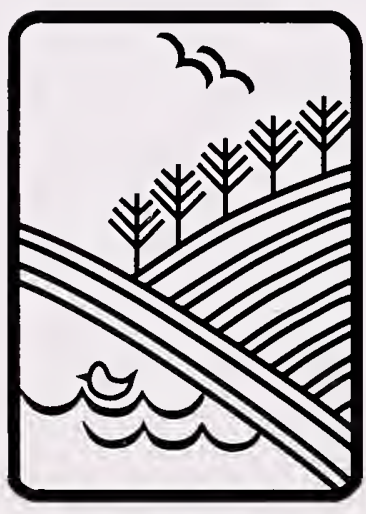

Great Plains
U.S. Department of Agriculture Forest Service

\section{Rocky Mountain Forest and Range Experiment Station}

The Rocky Mountain Station is one of seven regional experiment stations, plus the Forest Products Laboratory and the Washington Office Staff, that make up the Forest Service research organization.

\section{RESEARCH FOCUS}

Research programs at the Rocky Mountain Station are coordinated with area universities and with other institutions. Many studies are conducted on a cooperative basis to accelerate solutions to problems involving range, water, wildlife and fish habitat, human and community development, timber, recreation, protection, and multiresource evaluation.

\section{RESEARCH LOCATIONS}

Research Work Units of the Rocky Mountain Station are operated in cooperation with universities in the following cities:

Albuquerque, New Mexico

Flagstaff, Arizona

Fort Collins, Colorado*

Laramie, Wyoming

Lincoln, Nebraska

Rapid City, South Dakota

'Station Headquarters: 240 W. Prospect Rd., Fort Collins, CO 80526 